\title{
Promotion of weed species diversity and reduction of weed seedbanks with conservation tillage and crop rotation
}

Stephen D. Murphy

Department of Environment and Resource Studies, University of Waterloo, Waterloo, ON N2L 3G1, Canada

David R. Clements

Department of Biology, Trinity Western University, Langley, BC V2Y 1Y1, Canada

Svenja Belaoussoff

Department of Rural Sociology, University of Guelph, Guelph, ON N1G 2W1, Canada

Peter G. Kevan

Department of Environmental Biology, University of Guelph, Guelph, ON N1G 2W1, Canada

Clarence J. Swanton

Corresponding author. Department of Plant

Agriculture, University of Guelph, Guelph, ON

N1G 2W1, Canada; cswanton@uoguelph.ca
In a 6-yr study on four farms (36 fields) in Ontario, Canada, we tested the effects of tillage (moldboard, chisel plow, no tillage) and crop rotations (continuous corn, corn-soybean, corn-soybean-winter wheat) on emerged and seedbank weed species diversity and density. Aside from the imposed experimental treatments, all other management was generally consistent among farms. Tillage had the largest effect on weed diversity and density. No tillage promoted the highest weed species diversity, chisel plow was intermediate, and moldboard plow resulted in the lowest species diversity. These results are consistent with ecological succession theory. The increase in weed species diversity resulted from 20 species being associated with no tillage systems, 15 of which were winter annuals, biennials, or perennials. Emerged weed density was affected only by tillage. Over 6 yr, seedbank declined in no-tillage systems from 41,000 to 8,000 seeds $\mathrm{m}^{-3}$. Crop yields were not affected by tillage or crop rotation. In practical terms, reduced tillage in combination with a good crop rotation may reduce weed density and expenditures on weed management.

Nomenclature: Glyphosate; corn, Zea mays L. 'Pioneer 3902'; soybean, Glycine $\max (\mathrm{L}$.$) Merr. 'KG 40'; winter wheat Triticum aestivum L.$

Key words: No tillage, on-farm research, succession, weed density; weed life history.
Changes to farming practices, such as the adoption of conservation tillage, may present an unknown set of risks that can delay implementation by farmers (Weersink et al. 1992a, 1992b; Yiridoe et al. 1994). Clements et al. (1994) noted that changes in farm management systems will influence weed species diversity. This could be a threat to crop yields if some weed species are superior competitors and there are few management options available to farmers. However, potential benefits of increased weed species diversity include more competition between weed species, more niches for natural enemies of weeds, more weed-weed interactions, greater diversity of weed life histories (including less aggressive weed species), greater community stability, and reduced incidence of herbicide resistance (Andow 1983; Brust and House 1989; Buhler et al. 1994; Clements et al. 1994; Forcella et al. 1993; Froud-Williams 1988; Kremer 1993; Miyazawa et al. 2004; Schellhorn and Sork 1997; Swanton and Murphy 1996a, 1996b; Swift and Anderson 1993). The uncertainty surrounding the impact of changes in weed diversity is mirrored by a lack of studies explicitly evaluating changes in diversity in specific systems. Allowing increased weed diversity, including weed seedbank diversity, has been advocated for a variety of ecological reasons (Clements et al. 1994; Dekker 1999). These theoretical predictions are largely unproven and further empirical investigation is required (Clements et al. 1994; Derksen 1996).

One of the most significant changes in North American agriculture in the past several decades has been the adoption of conservation tillage. Conservation tillage, especially no tillage, has been promoted to reduce soil erosion, runoff of pesticides and fertilizers, and pesticide use (Fawcett et al. 1994; Karlen et al. 1994; Swanton and Murphy 1996a;
Swanton and Weise 1991). Results have indicated that crop yields under conservation tillage may not decrease if the system is managed properly, allowing time for farmers to adapt to a new system (Ball et al. 1994; Cannell and Hawes 1994; Swanton et al. 1999). Nonetheless, there are concerns about the long-term viability of reduced or no tillage, such as wildly fluctuating weed population dynamics and potential colonization by weed species that are perceived to be harder to manage: perennials, grasses, wind-borne species, and volunteer crops (Allmaras and Dowdy 1985; FroudWilliams et al. 1983; Hinkle 1983; Koskinen and McWhorter 1986; Thomas and Frick 1993).

Some experimental results have dispelled these fears, but it may be unwise to overgeneralize about the effects of farm management on weeds because there are relatively few longterm and on-farm studies (Bilalis et al. 2001; Buhler 1995; Derksen 1996; Derksen et al. 1993, 1994, 1995; Légére and Samson 1999). Increases in diversity under no tillage are predicted because the successional trajectory of the weed community is allowed to proceed further than under conventional tillage (Swanton et al. 1993). Swanton et al. (1993) advocated long-term studies to monitor successional change occurring beyond the initial fluctuations that occur in the first few years following the adoption of reduced tillage.

Crop rotation also affects weed communities because the crop itself and the management regime associated with it create different habitats for weed species (Clements et al. 1994; Liebman and Dyck 1993). Adopting a complex rotation in conjunction with conservation tillage may reduce risks associated with reduced tillage, while increasing weed species diversity across the rotation. Based on tillage and 
crop rotation research in South Dakota, Kegode et al. (1999) recommended that a combination of reduced tillage and longer crop rotations be employed to reduce weed seed production.

Although emerged weeds usually provide the primary indicator of the success of weed management efforts, monitoring the seedbank can offer additional information about the long-term prognosis for weed management. Seedbanks act as the "memory" of the population dynamics of weeds over several years, reflecting past and present management elements, and they are an indication of weed problems to come (Cavers 1995; Dorado et al. 1999). Changes to the emerged weed populations represent relatively immediate impacts of changing farming practices, whereas changes to the seedbank may be more representative of long-term trends associated with changes in farming practices (Buhler et al. 1997; Dekker 1999).

We designed an on-farm study to address whether changes to tillage (and other farming practices) affected the density or species diversity of emerged and seedbank weeds. This study follows from an earlier review that called for more research on weed species succession following reduced tillage (Swanton et al. 1993). Our objective was to determine whether reduced tillage or more diverse crop rotations increased weed diversity.

\section{Materials and Methods}

To test whether farming system affected weed species diversity and the weed community at large, we sampled four farming operations using a balanced design. The farms were located in Wellington and Oxford Counties and the Regional Municipality of Waterloo of southwestern Ontario, Canada. Farms were selected based on similarity of management history, crops grown, rotations used, amendments used, proximity within a geographic location, and availability of fields to allow us to compare clusters of fields between counties and regions that differed in climate and soil characteristics, i.e., would weed diversity respond consistently across different growing regions in Ontario? Farmers selected their crop varieties based on personal preference, number of growing degree days to crop maturity, and farming experience. All farmers used identical seeding patterns: corn planted in 76-cm rows at 75,000 seeds $\mathrm{ha}^{-1}$, soybean planted in $53-\mathrm{cm}$ rows at 50,000 seeds $\mathrm{ha}^{-1}$, and winter wheat planted in $18-\mathrm{cm}$ rows at 50,000 seeds $\mathrm{ha}^{-1}$. In the spring of each year, winter wheat was underseeded with red clover (Trifolium pratense L.) at a rate of 10 to $12 \mathrm{~kg} \mathrm{ha}^{-1}$. Farmers used one of three crop rotation approaches: no rotation (continuous corn), corn-soybean, or corn-soybean-winter wheat. In each of the three regions or counties, we examined two farm fields of each of six management classifications (36 fields in total):

- No tillage and a three-crop rotation (corn-soybeans-winter wheat)

- No tillage and a two-crop rotation (corn-soybeans)

- Chisel plow and a three-crop rotation (corn-soybeans-winter wheat)

- Chisel plow and a two-crop rotation (corn-soybeans)

- Moldboard plow and a three-crop rotation (corn-soybeans-winter wheat)

- Moldboard plow and no rotation (continuous corn)
Soil types in these counties and regions differed. All Wellington farms had Conestoga silty loam, Melanic Brunisol soil, typically having $30 \%$ sand, $50 \%$ silt, $20 \%$ clay, 5\% organic matter, and a pH of 6.6 to 6.8. All Waterloo and Oxford farms had Gray-Brown Podzolic soils, typically characterized by $50 \%$ sand, $35 \%$ silt, $15 \%$ clay, $5 \%$ organic matter, and a $\mathrm{pH}$ of 6.5 to 6.8 .

Our main variables across farms were tillage and crop rotation; most other variables (e.g., pesticides and fertilizers used) were relatively consistent across farms, which reduced confounding effects. All farmers had switched some of their fields to no tillage during 1991 to 1992 (2 yr before our observations began) and had used their crop rotation sequence since that time. All farmers applied broadcasted fertilizer of approximately $150,40,40 \mathrm{~kg} \mathrm{ha}^{-1}$ of NPK for corn; $100 \mathrm{~kg} \mathrm{ha}^{-1} \mathrm{~K}$ before soybeans; $80,30,0 \mathrm{~kg} \mathrm{ha}^{-1}$ of NPK for winter wheat, respectively. Depending on the year and the emergence pattern of the weeds one to two applications of glyphosate were applied at $0.9 \mathrm{~kg}^{\mathrm{ai} \mathrm{ha}} \mathrm{ha}^{-1}$ as a burn down herbicide in all rotations and in all years. When planting corn, farmers applied pre-emergence tank mixes of linuron and metalochlor (1.1 and $1.9 \mathrm{~kg}$ ai ha ${ }^{-1}$, respectively). For soybean, pre-emergence tank mixes of metalochlor and imazethapyr (2.0 and $1.0 \mathrm{~kg}$ ai ha ${ }^{-1}$, respectively) were used. In winter wheat, postemergence tank mixes of dicamba, MCPA, and mecoprop were all applied at $0.5 \mathrm{~kg}$ ai ha ${ }^{-1}$. The herbicide rates were in accordance with recommendations in the Ontario Guide to Weed Control (e.g., Ontario Weed Committee 1996). Dominant weeds across all farm locations included common lambsquarters (Chenopodium album L.), redroot pigweed (Amaranthus retroflexus L.), common ragweed (Ambrosia artemisifolia L.), barnyardgrass [Echinochloa crus-galli (L.) Beauv.], and annual and perennial sowthistle (Sonchus oleraceus L. and Sonchus arvensis L.). Problem perennial weeds found in individual fields were controlled with spot treatments of glyphosate.

In the last week of May, July, and September, in 19941999 , we assessed weed diversity in each field using a modified stratified random design with permanent transects and quadrats. We counted every emerged shoot in ten $1-\mathrm{m}^{2}$ quadrats along each of five 100-m transects from each farm field. In mid-June, emerged weed density (shoots $\mathrm{m}^{-2}$ ) of every species was recorded using the same transects and quadrats. In early July, we re-sampled for evidence of changes in herbivory and pathogenic infection of weeds by randomly selecting ten weeds of various species from each of ten $1-\mathrm{m}^{2}$ quadrats along each of five $100-\mathrm{m}$ transects from each farm field. Plants were stored at $5 \mathrm{C}$ in paper bags in a laboratory-grade refrigerator-freezer. The number of leaves on each plant with insect (herbivore) damage or rust infection was counted; we were unable to quantitatively assess the relative damage to stems or roots; hence, our data are limited to leaf herbivores and pathogens. In late September each year, crop yields were sampled in each field as the farmers harvested the area; bulk crop yields (for the entire field) were reported. Samples were oven dried at $70 \mathrm{C}$ for $72 \mathrm{~h}$ and dry weights measured. Yields were then recalculated using appropriate grain moisture levels.

To collect seedbank data, twenty-five $188-\mathrm{cm}^{3}(15 \mathrm{~cm}$ deep by $2 \mathrm{~cm}$ radius) soil samples were collected from each field in late September of all years. Samples were collected within a $5 \mathrm{~m}^{2}$ area surrounding each quadrat (outside of 
TABLE 1. Analysis of variance of repeated measures comparing Shannon-Weiner diversity indices for emerged weeds and seeds in the seedbank among farm locations, sampling locations within a farm, and farming systems. For emerged weeds, time represents variation caused by different survey months and years.

\begin{tabular}{|c|c|c|c|c|c|c|}
\hline \multirow[b]{2}{*}{ Source of variation } & \multicolumn{2}{|c|}{ MS } & \multicolumn{2}{|c|}{$F$} & \multicolumn{2}{|c|}{$\mathrm{P}$} \\
\hline & Emerged & Seedbank & Emerged & Seedbank & Emerged & Seedbank \\
\hline \multicolumn{7}{|l|}{ Between-subjects } \\
\hline Sampling location within farm & 1.94 & 1.82 & 2.53 & 2.40 & 0.317 & 0.368 \\
\hline Farming system & 47.14 & 39.81 & 55.63 & 48.62 & $<0.001$ & $<0.001$ \\
\hline Farm location f farming system & 0.14 & 0.86 & 0.57 & 0.93 & 0.774 & 0.741 \\
\hline \multicolumn{7}{|l|}{ Within-subjects } \\
\hline Time & 62.87 & 55.87 & 99.18 & 90.24 & $<0.001$ & $<0.001$ \\
\hline Farming system $\cdot$ time & 2.65 & 3.43 & 4.41 & 5.98 & 0.221 & 0.197 \\
\hline Sampling location t time & 1.57 & 1.42 & 2.09 & 1.99 & 0.372 & 0.377 \\
\hline Farm location time & 1.11 & 1.68 & 1.63 & 2.51 & 0.536 & 0.401 \\
\hline Error & 1.29 & 1.07 & 1.85 & 1.54 & 0.416 & 0.487 \\
\hline
\end{tabular}

the area used for diversity measurements). In the lab, each sample was placed in a 3-cm-deep container lined with peat. The containers were placed in a growth room $(T=25 \mathrm{C}$; photoperiod $=16 / 8$ light/dark) from October to March, and watered daily. The soil was stirred monthly, and samples were frozen in late December for $1 \mathrm{wk}$ to break seed dormancy in species with a freezing requirement (Benoit et al. 1991). Numbers of emerging seedlings were recorded weekly (for $12 \mathrm{mo}$ ) for each sample and reported and analyzed per sample.

\section{Calculations and Statistical Analysis}

To assess weed diversity we calculated the Shannon-Weiner diversity index $(H)$ for each replicate. The ShannonWeiner diversity index formula is:

$$
H=\mathrm{E}\left(p_{i}\right)\left(\log _{2} p_{i}\right)
$$

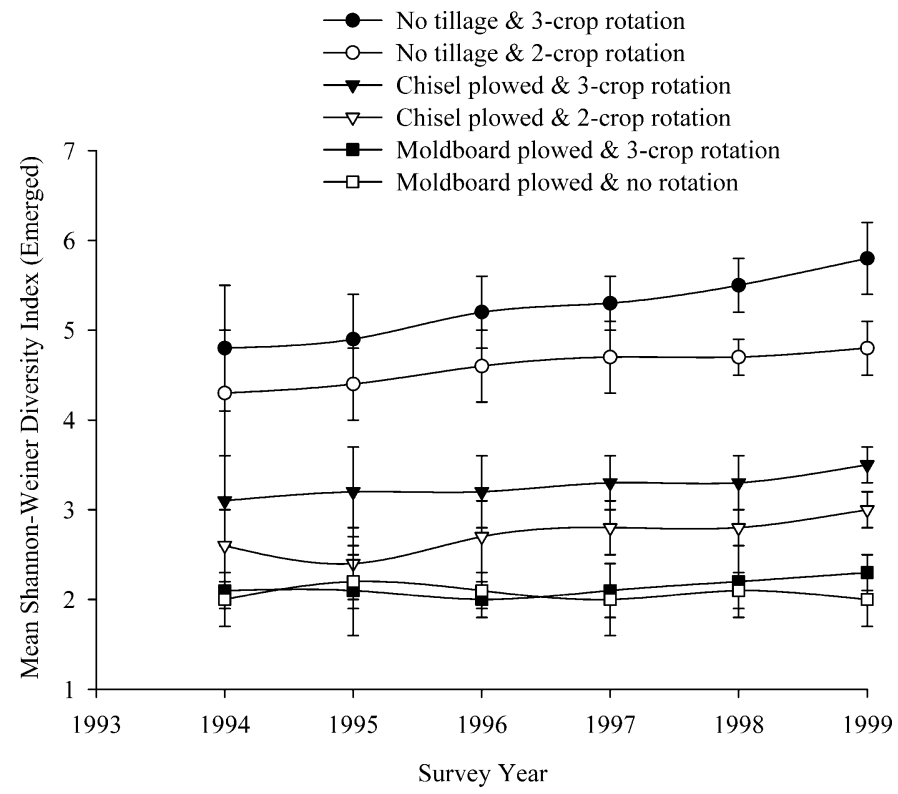

FIGURE 1. Changes in mean Shannon-Weiner Diversity Index $( \pm S E)$ for emerged weeds in July from 1994 to 1999 (data pooled across all locations). where $H$ is species diversity and $p_{i}$ is the proportion of individuals in the total sample belonging to the $i$ th species. The Shannon-Weiner index is a measure of diversity widely used in community ecology and accounts for proportional abundance and number of species within a single value (Clements et al. 1994; Magurran 1988).

We used SPSS version 8.0 to analyze all data. We first used analyses of variance with repeated measures (ANOVARs) to test for differences between years and locations. We used two-factor analyses of variance (ANOVAs) with contrasts for comparisons within years and between treatments to separate which management systems caused differences in responses. For the percentage data on herbivory and fungal infections, arcsine-square root transformations were used to normalize the data.

\section{Results and Discussion}

\section{Reduced Tillage and Longer Crop Rotations Increased Emerged and Seedbank Weed Species Diversity}

The key effects on diversity were farming system (rotation and tillage) and time (Table 1). The effect of time means that differences among diversity indices became more pronounced over time (Figure 1-all figures are reported for mid-July surveys to show long-term effects of management differences). In addition, the effect of time reflects the fact that there was significant between-year variation within each tillage-crop rotation combination (Table 1). However, the results comparing the effect of these combinations on weed species diversity remained consistent (Table 2), although the actual taxa of weed species differed among locations, i.e., the impacts on species diversity were similar, though any given field might have very different species. The reason for weed population differences likely relates to different nearby weed propagule sources, site histories, soil types, or local environmental variation (Andersson and Milberg 1998; Buhler et al. 1994; Derksen et al. 1994). The consistency of effects indicated a lack of confounding effects and the care taken to choose farmers who used similar management approaches so the data would be comparable. 
TABLE 2. Contrasts comparing effects of tillage and crop rotation on Shannon-Weiner diversity index values for emerged weeds and seeds in the seedbank (data pooled across all years; Table 1 showed no confounding effects of within-subject effects).

\begin{tabular}{|c|c|c|c|c|c|c|}
\hline \multirow[b]{2}{*}{ Contrast } & \multicolumn{2}{|c|}{ MS } & \multicolumn{2}{|c|}{$F$} & \multicolumn{2}{|c|}{$\mathrm{P}$} \\
\hline & Emerged & Seedbank & Emerged & Seedbank & Emerged & Seedbank \\
\hline No-till 3-crop vs. no-till 2-crop & 8.16 & 10.15 & 9.14 & 12.43 & $<0.01$ & $<0.01$ \\
\hline No-till 3-crop vs. chisel plow 3-crop & 15.87 & 23.22 & 18.21 & 25.76 & $<0.001$ & $<0.001$ \\
\hline No-till 3-crop vs. chisel plow 2-crop & 19.03 & 26.71 & 24.08 & 28.00 & $<0.001$ & $<0.001$ \\
\hline No-till 3-crop vs. moldboard plow 3-crop & 40.13 & 44.92 & 49.17 & 47.13 & $<0.001$ & $<0.001$ \\
\hline No-till 3-crop vs. moldboard plow 1-crop & 66.91 & 70.54 & 72.30 & 71.45 & $<0.001$ & $<0.001$ \\
\hline No-till 2-crop vs. chisel plow 3-crop & 11.74 & 13.22 & 12.54 & 14.56 & $<0.01$ & $<0.01$ \\
\hline No-till 2-crop vs. chisel plow 2-crop & 16.75 & 19.07 & 26.72 & 22.11 & $<0.001$ & $<0.001$ \\
\hline No-till 2-crop vs. moldboard plow 3-crop & 67.66 & 73.41 & 70.49 & 76.52 & $<0.001$ & $<0.001$ \\
\hline No-till 2-crop vs. moldboard plow 1-crop & 61.32 & 65.01 & 63.91 & 68.96 & $<0.001$ & $<0.001$ \\
\hline Chisel plow 3-crop vs. chisel plow 2-crop & 9.81 & 10.88 & 10.76 & 14.07 & $<0.01$ & $<0.01$ \\
\hline Chisel plow 3-crop vs. moldboard plow 3-crop & 6.13 & 10.25 & 7.15 & 12.85 & $<0.01$ & $<0.01$ \\
\hline Chisel plow 3-crop vs. moldboard plow 1-crop & 31.55 & 36.99 & 37.84 & 38.72 & $<0.001$ & $<0.001$ \\
\hline Chisel plow 2-crop vs. moldboard plow 3-crop & 17.48 & 19.91 & 19.06 & 22.33 & $<0.001$ & $<0.001$ \\
\hline Chisel plow 2-crop vs. moldboard plow 1-crop & 25.44 & 26.73 & 28.64 & 28.74 & $<0.001$ & $<0.001$ \\
\hline Moldboard plow 3-crop vs. moldboard plow 1-crop & 5.20 & 7.30 & 6.67 & 8.91 & $<0.01$ & $<0.01$ \\
\hline
\end{tabular}

The highest emerged and seedbank weed species diversity occurred in no-tillage fields with a three-crop rotation of corn-soybean-winter wheat (Table 2; Figures 1 and 2). No tillage promoted the highest weed species diversity, chisel plowing resulted in intermediate weed species diversity, and moldboard plowing resulted in the lowest weed species diversity (Table 2; Figure 1). Similarly in other studies, Shannon-Weiner index calculations have also indicated higher weed seedbank diversity in no-tillage vs. moldboard plow systems ( 1.20 vs. 0.70$)$ in Ohio test plots (Cardina et al. $1991)$ and higher emerged weed species diversity (1.31 vs. 0.97) in Saskatchewan plot studies (Derksen 1991). Our values for the Shannon-Weiner index are higher than those previously reported. Farmers in our study had made a recent change to adopt reduced tillage. The Shannon-Weiner index considers both species number and their abundances so a higher index indicates that many rare species were present.

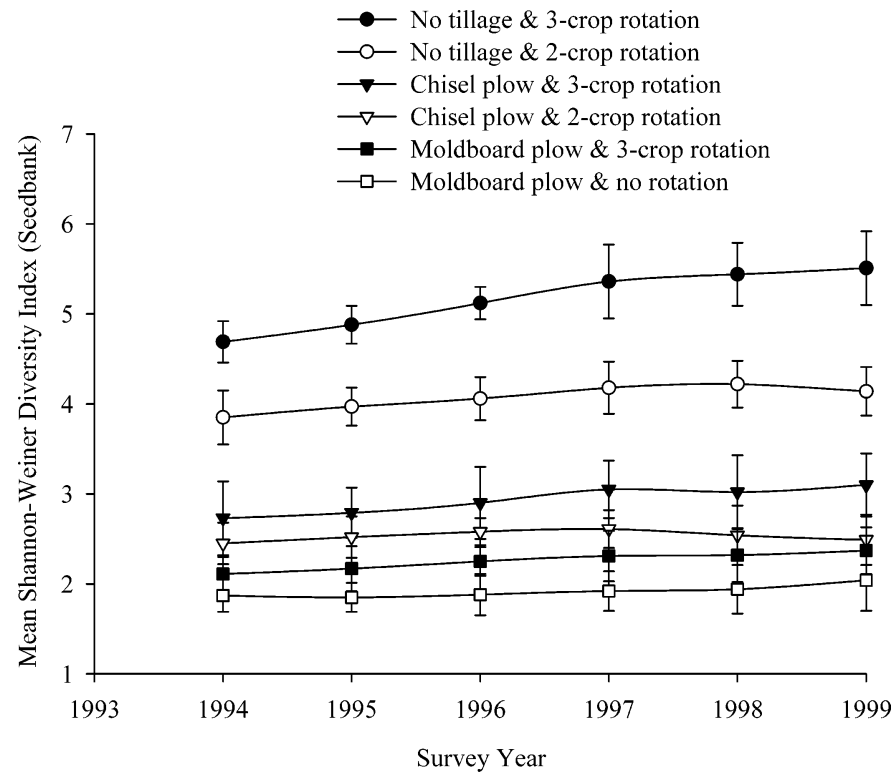

Figure 2. Changes in mean value of Shannon-Weiner Diversity Index ( \pm SE) for weeds in the seedbank from 1994 to 1999 (data pooled across all locations).
In a similar study, Miyazawa et al. (2004) had indices of over 1.5 in some no-till sites.

The fact that weed species diversity increased with reduced tillage and a three-species crop rotation supports earlier predictions found in other papers (e.g., Clements et al. 1994; Swanton et al. 1993). The reduction of soil disturbance and other microenvironmental changes created by no tillage and crop rotations probably changes selection pressures, so that formerly dominant species are no longer at a large selective advantage (Blumberg and Crossley 1983; Cromar et al. 1999; Dick and Daniel 1987; Hendrix et al. 1986; House and Brust 1989; House and Parmelee 1985; House et al. 1984; Swanton and Murphy 1996b). Compared with continuous monoculture, diverse rotation may differ in the light transmitted through the crop canopy, the herbicide(s) used, the timing of tillage operations, and the natural enemies living in the crop; these conditions presumably make it difficult for one weed species to dominate the weed community (Altieri 1995; Caporali and Onnis 1992; Clay and Aguilar 1998; Clements et al. 1994; Dekker 1997; Dorado et al. 1999; Liebman and Dyck 1993).

The effect on species diversity was more pronounced (though not in the sense of being statistically comparable) in seedbank data than in emerged weed data (Figures 1 and 2). We interpret this as meaning that the formerly dominant species in tillage-intensive and no- or low-rotation fields were contributing fewer seeds and more species were contributing seeds. In tillage-intensive fields, a small number of species tend to dominate, i.e., comprise 70 to $90 \%$ of the total seedbank (Wilson 1988). The key issue then becomes whether the increasingly diverse seedbank translates into an increase in weed density or the introduction of particularly problematic weeds because, in the short term, these will create weed management problems for farmers.

\section{Reduced Tillage and Crop Rotations Decreased Weed Seedbank Density}

As with diversity, the important variables influencing density were farming system and time (Table 3 ). When we tested whether there were changes in weed densities with more 
TABLE 3. Analysis of variance of repeated measures comparing densities for emerged weeds and weed seeds in the seedbank among farm locations, sampling locations within a farm, and farming systems.

\begin{tabular}{|c|c|c|c|c|c|c|}
\hline \multirow[b]{2}{*}{ Source of variation } & \multicolumn{2}{|c|}{ MS } & \multicolumn{2}{|c|}{$F$} & \multicolumn{2}{|c|}{$\mathrm{P}$} \\
\hline & Emerged & Seedbank & Emerged & Seedbank & Emerged & Seedbank \\
\hline \multicolumn{7}{|l|}{ Between-subjects } \\
\hline $\begin{array}{l}\text { Farm location } \\
\text { Sampling location within farm } \\
\text { Farming system } \\
\text { Farm location } \cdot \text { farming system } \\
\text { Sampling location } \cdot \text { farming system } \\
\text { Error }\end{array}$ & $\begin{array}{r}2.15 \\
2.81 \\
29.81 \\
0.92 \\
1.25\end{array}$ & $\begin{array}{r}1.88 \\
2.94 \\
33.44 \\
1.18 \\
1.27\end{array}$ & $\begin{array}{r}2.49 \\
2.76 \\
41.02 \\
1.16 \\
1.29\end{array}$ & $\begin{array}{r}2.22 \\
3.04 \\
48.49 \\
1.52 \\
1.36\end{array}$ & $\begin{array}{r}0.327 \\
0.311 \\
<0.001 \\
0.571 \\
0.467\end{array}$ & $\begin{array}{r}0.393 \\
0.286 \\
<0.001 \\
0.552 \\
0.453\end{array}$ \\
\hline \multicolumn{7}{|l|}{ Within-subjects } \\
\hline $\begin{array}{l}\text { Time } \\
\text { Farming system } \cdot \text { time } \\
\text { Sampling location } \cdot \text { time } \\
\text { Farm location·time } \\
\text { Error }\end{array}$ & $\begin{array}{r}28.77 \\
3.71 \\
2.86 \\
3.35 \\
0.68\end{array}$ & $\begin{array}{r}29.09 \\
2.81 \\
2.99 \\
3.05 \\
0.74\end{array}$ & $\begin{array}{r}37.54 \\
4.81 \\
3.26 \\
3.79 \\
0.92\end{array}$ & $\begin{array}{r}40.22 \\
5.89 \\
4.13 \\
3.41 \\
1.03\end{array}$ & $\begin{array}{r}<0.001 \\
0.164 \\
0.358 \\
0.364 \\
0.693\end{array}$ & $\begin{array}{r}<0.001 \\
0.379 \\
0.326 \\
0.468 \\
0.642\end{array}$ \\
\hline
\end{tabular}

diverse weed populations, we found that there was little short-term risk to farmers in terms of emerged or seedbank densities. As weed species diversity increased following the establishment of no-tillage fields, emerged weed densities were not affected (Figure 3; lines are absent because the variation makes it difficult to read otherwise). In contrast, seedbank densities declined in no-tillage and chisel-plowed fields but remained constant in moldboard plow systems over the $6 \mathrm{yr}$ of the study (Tables 3 and 4; Figures $4 \mathrm{a}$ and $4 \mathrm{~b}$; no tillage is separated because its decline was quite dramatic). The mean weed seed density in no-tillage fields with a three-crop rotation decreased from approximately 41,000 seeds $\mathrm{m}^{-3}$ of soil in 1994 to 8,000 seeds $\mathrm{m}^{-3}$ in 1999 (Figure 4). Mean weed seed density in chisel-plowed fields was still at 34,000 seeds $\mathrm{m}^{-3}$ of soil in the three-crop system in 1999 and moldboard-plowed fields remained relatively constant at about 49,000 seeds $\mathrm{m}^{-3}$ of soil (Figure 4). There were no significant differences in emerged weed density (Tables 3 and 4).

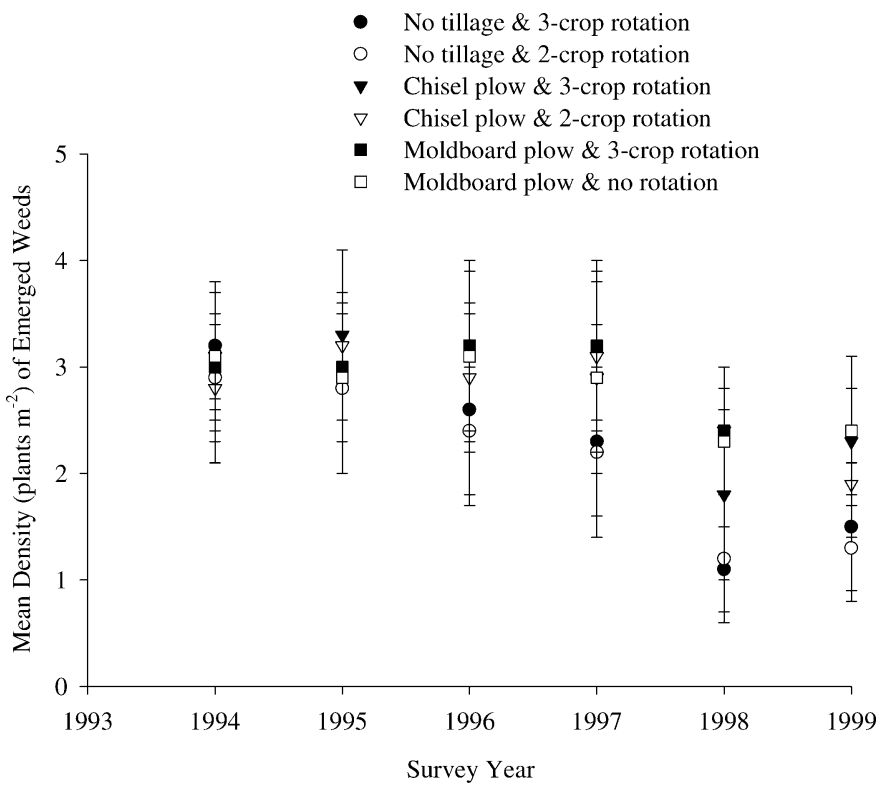

FIGURE 3. Changes in mean density ( \pm SE) for emerged weeds from 1994 to 1999 (data pooled across all locations).
Some studies have shown that as tillage was reduced seedbank density decreased or remained relatively unchanged (Ball 1992; Ball and Miller 1993; Ball and Shaffer 1993; Clements et al. 1994). For example, Clements et al. (1996) observed a seedbank density of less than $800 \mathrm{~m}^{-2}$ in the top $15 \mathrm{~cm}$ of a no tillage system compared with $2,667 \mathrm{~m}^{-2}$ in a moldboard-plowed system, after $7 \mathrm{yr}$ in a corn-soybean rotation in southern Ontario. Similarly, Liebman and Dyck (1993) reported a decrease in emerged and seedbank density with increased rotational diversity; of 27 rotations they analyzed, emerged weed density was reduced or equivalent to that in monoculture in all but one of the rotations. Weed seed density was lower in diverse rotations than in monocultures in 9 of the 12 instances where weed seed density was reported and equivalent in the other three.

Again, decreased seed density in diverse rotations likely reflects changes in selection pressures via changes in management. Reduced tillage often facilitates destruction of more weed seeds before they reach the seedbank or prevents them from germinating. In our study, it appears that the main mechanism is destruction of seeds rather than prevention of germination, given the actual decline in seed densities in the seedbanks. Reduced tillage may create conditions where weeds lie on the surface or are buried at very shallow depths. This can increase desiccation of weed seeds, death rates of weed seedlings unable to access water quickly enough after germination, destruction of weeds by herbivores and parasites, and the effectiveness of herbicides (Buhler 1995; Buhler et al. 1997; Clements et al. 1996; Cromar et al. 1999; Roman et al. 2000; Swanton and Murphy 1996b; Swanton et al. 1999). It remains to be tested whether weeds will adapt to new tillage and rotation conditions quickly and whether seedbank densities will decline enough so emerged weed densities will also decline.

Management practices such as reduced tillage did not exacerbate weed densities, despite the oft-cited concern from farmers (especially) that this may happen (Allmaras and Dowdy 1985; Froud-Williams et al. 1983; Hinkle 1983; Koskinen and McWhorter 1986; Thomas and Frick 1993). Hoffman et al. (1998) concluded that if weed seed numbers sometimes appeared to increase in reduced tillage, it was not because of the tillage practice itself, but because of associated weed management practices such as banding or eliminating 
TABLE 4. Contrasts comparing densities for emerged weeds and weeds in the seedbank (data pooled across all years; Table 1 showed no confounding effects of within-subject effects).

\begin{tabular}{|c|c|c|c|c|c|c|}
\hline \multirow[b]{2}{*}{ Contrast } & \multicolumn{2}{|c|}{ MS } & \multicolumn{2}{|c|}{$F$} & \multicolumn{2}{|c|}{$\mathrm{P}$} \\
\hline & Emerged & Seedbank & Emerged & Seedbank & Emerged & Seedbank \\
\hline No-till 3-crop vs. no-till 2-crop & 1.14 & 4.27 & 1.96 & 7.02 & 0.501 & $<0.01$ \\
\hline No-till 3-crop vs. chisel plow 3-crop & 1.35 & 71.45 & 2.07 & 78.56 & 0.436 & $<0.001$ \\
\hline No-till 3-crop vs. chisel plow 2-crop & 1.67 & 78.72 & 2.25 & 84.41 & 0.422 & $<0.001$ \\
\hline No-till 3-crop vs. moldboard plow 3-crop & 2.99 & 89.06 & 3.62 & 93.90 & 0.358 & $<0.001$ \\
\hline No-till 3-crop vs. moldboard plow 1-crop & 3.42 & 94.13 & 4.00 & 96.54 & 0.334 & $<0.001$ \\
\hline No-till 2-crop vs. chisel plow 3-crop & 1.56 & 64.31 & 1.81 & 68.06 & 0.487 & $<0.001$ \\
\hline No-till 2-crop vs. chisel plow 2-crop & 0.92 & 54.90 & 1.27 & 57.32 & 0.577 & $<0.001$ \\
\hline No-till 2-crop vs. moldboard plow 3-crop & 2.30 & 91.32 & 2.46 & 94.55 & 0.381 & $<0.001$ \\
\hline No-till 2-crop vs. moldboard plow 1-crop & 2.94 & 97.56 & 3.15 & 99.04 & 0.313 & $<0.001$ \\
\hline Chisel plow 3-crop vs. chisel plow 2-crop & 0.74 & 0.66 & 0.95 & 0.87 & 0.624 & 0.530 \\
\hline Chisel plow 3-crop vs. moldboard plow 3-crop & 0.81 & 5.79 & 1.11 & 6.17 & 0.579 & $<0.05$ \\
\hline Chisel plow 3-crop vs. moldboard plow 1-crop & 2.02 & 6.12 & 2.43 & 6.54 & 0.468 & $<0.05$ \\
\hline Chisel plow 2-crop vs. moldboard plow 3-crop & 1.13 & 4.99 & 1.37 & 5.53 & 0.630 & $<0.05$ \\
\hline Chisel plow 2-crop vs. moldboard plow 1-crop & 2.35 & 6.17 & 2.61 & 6.80 & 0.449 & $<0.05$ \\
\hline Moldboard plow 3-crop vs. moldboard plow 1-crop & 0.95 & 0.38 & 1.08 & 0.51 & 0.582 & 0.784 \\
\hline
\end{tabular}
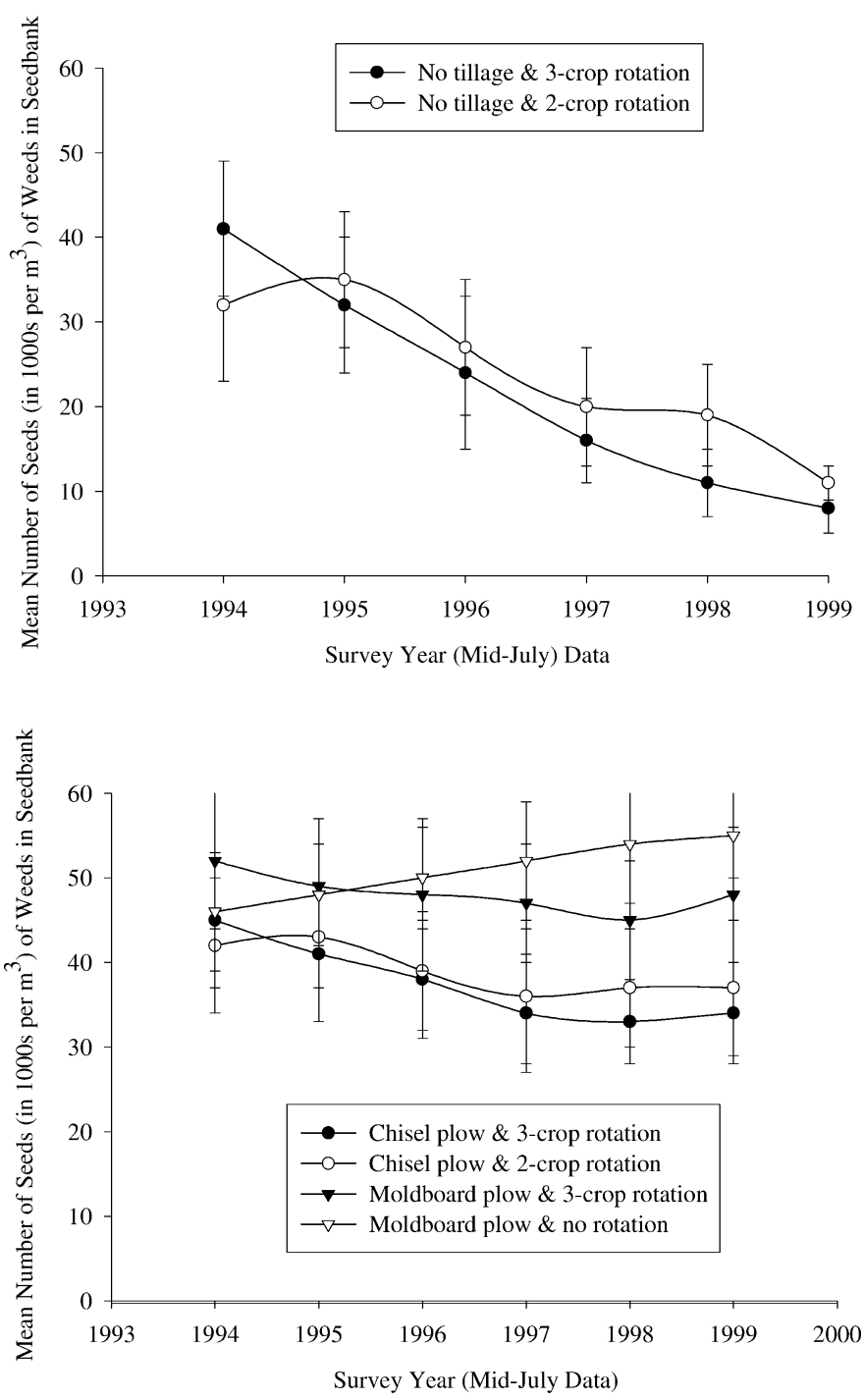

FigURE 4. Changes in mean number of weed seeds $( \pm$ SE) in the seedbank from 1994 to 1999 in no tillage and chisel and moldboard-plowed plots (data pooled across all locations). herbicides (Buhler 1995; Cardina et al. 1991; Dale et al. 1992; Dorado et al. 1999; Yenish et al. 1992). Because farmers in our study used broadcast methods at recommended rates, our results were similar to Hoffman et al. (1998) as they found that total numbers of seeds were reduced in no tillage when weed populations recruited from seeds in the top $5 \mathrm{~cm}$ of soil were adequately controlled by weed management practices.

The "bad news" is that there was still sufficient seed production after $6 \mathrm{yr}$ (plus $2 \mathrm{yr}$ previous to observation when no tillage had been established in some fields) to maintain a constant emerged weed population in all management systems (Figure 3). The "good news" is that (a) changing management systems to no-tillage or three-crop rotation did not increase immediate risk from weed densities, and (b) because the seedbank density declined rapidly (Figure 4), it is possible that the future emerged weed density will decline for some species in no-tillage systems, in particular.

\section{Herbivory and Disease Damages Were Higher in No Tillage}

In our study, no tillage tended to promote more herbivory and pathogenic infection of weeds (Table 5). Among weeds sampled in the final $3 \mathrm{yr}$ from the no tillage rotations, 39 to $65 \%$ suffered herbivory and 45 to $79 \%$ were infected by rust pathogens, whereas in the chisel plow and moldboard plow systems, the highest percentages for herbivory and rust incidence were $21 \%$ and $20 \%$, respectively. Although this provides only a superficial analysis of the effects of herbivores and pathogens on weeds in these systems, the magnitude of the difference calls for further investigation. Increased weed diversity, as seen in the no-tillage fields, may increase indirectly faunal diversity. On average, each weed species may support about a dozen phytophagous or entomophagous animal species (El Titi 1995). Evidence suggests that manipulation of certain weed species may improve the regulation of insect pests (Altieri and Whitcomb 1979, 1980) or simultaneously decrease insect pest populations and increase weed-weed competition (Andow 1983). Such manipulation is facilitated by a more diverse weed community. 
TABLE 5. Analysis of variance of repeated measures comparing damage to weed leaves from herbivory and rust fungi between farm locations, between sampling locations within a farm, and between farming systems.

\begin{tabular}{|c|c|c|c|c|c|c|}
\hline \multirow[b]{2}{*}{ Source of variation } & \multicolumn{2}{|c|}{ MS } & \multicolumn{2}{|c|}{$F$} & \multicolumn{2}{|c|}{$\mathrm{P}$} \\
\hline & Herbivory & Fungi & Herbivory & Fungi & Herbivory & Fungi \\
\hline \multicolumn{7}{|l|}{ Between-subjects } \\
\hline Farm location & 3.58 & 4.11 & 4.09 & 4.85 & 0.277 & 0.151 \\
\hline Sampling location within farm & 2.73 & 2.42 & 2.98 & 2.61 & 0.345 & 0.382 \\
\hline Farming system & 28.97 & 21.93 & 35.89 & 26.74 & $<0.001$ & $<0.001$ \\
\hline Farm location·farming system & 2.44 & 2.91 & 2.80 & 3.26 & 0.572 & 0.483 \\
\hline Sampling location $\cdot$ farming system & 1.53 & 1.94 & 1.77 & 2.00 & 0.629 & 0.581 \\
\hline Error & 0.76 & 0.53 & 1.11 & 0.89 & 0.743 & 0.784 \\
\hline \multicolumn{7}{|l|}{ Within-subjects } \\
\hline Time & 51.73 & 42.28 & 58.90 & 47.99 & $<0.001$ & $<0.001$ \\
\hline Farming system $\cdot$ time & 4.38 & 2.78 & 4.71 & 2.95 & 0.183 & 0.370 \\
\hline Sampling location-time & 2.71 & 3.96 & 2.98 & 4.27 & 0.399 & 0.227 \\
\hline Farm location-time & 3.29 & 3.15 & 3.63 & 3.41 & 0.284 & 0.306 \\
\hline Error & 1.37 & 1.89 & 1.58 & 2.13 & 0.562 & 0.516 \\
\hline
\end{tabular}

\section{Crop Yields Were Not Affected by Any Treatment Factor}

There were no crop-yield differences related to any treatment factor though location was a significant influence (data not shown). Though there was (nonsignificant) year to year variation, corn, soybean, and wheat yields remained relatively constant for Waterloo Region and Oxford County (approximately 8.5 and $2.5 \mathrm{Mg} \mathrm{ha}^{-1}$, and $3.1 \mathrm{Mg} \mathrm{ha}^{-1}$, respectively, across the farms). The only significant effect detected from the ANOVAR was for "farm location" where $F=8.53, P<0.05$; contrasts (not reported) indicated yields were lower on all Wellington County farms with the exception of wheat (means for corn and soybeans were around 7.8 and $2.1 \mathrm{Mg} \mathrm{ha}^{-1}$, respectively). This difference was probably related to differences in soil types and climate. Our overall results were similar to other studies that have found little or no difference between yields under conventional and conservation tillage (Ball et al. 1994; Cannell and Hawes 1994).

\section{Increased Weed Species Diversity May Be Neutral or Beneficial: Monitoring is Needed}

One of the advantages of on-farm research is that it provides a learning experience for both researchers and farmers (Hildebrand and Poey 1985). Hence, farmers participating in this study provided useful insights, particularly in terms of evaluating perceived risks associated with conservation tillage. Anecdotally, participating farmers recognized that they were encountering an increased diversity of weed species but were pleased that they were not suffering any unusual crop yield losses. In general, the farmers using notillage and three-crop rotations expected a net annual economic gain because of reduced inputs but, as yet, were not able to provide evidence of a long-term economic gain. This is mainly because of capital costs of new (no-tillage or chisel plow) equipment purchases in the period just before 1994 (in fact, they did not expect to see any gain until past 2000). Economic analyses in Ontario have reported similar annual profitability among tillage systems (Weersink et al. 1992a, 1992b; Yiridoe et al. 1994, 2000).

Any expected gains in yield or profit assumes that no new weed species will present an insurmountable threat to crop yield. Most farmers would likely agree that any new weed species detected should be monitored. For example, in Ontario, horseweed [Conyza canadensis (L.) Cronq.] and wild cucumber [Echinocystis lobata (Michx.) T. \& G.] were encountered frequently in association with corn fields under no till. In our study, 20 new species not commonly encountered in conventional tillage were recorded (Table 6).

The association of the most abundant of these species, horseweed, with reduced tillage systems has long been recognized (Triplett and Lytle 1972), whereas this is the first published report of the occurrence in no tillage for many of these species. In general, the species specific to no tillage do not seem to pose a threat to crop yields relative to losses from weeds such as common lambsquarters that tend to dominate moldboard-plowed fields. Only 5 of the 20 species contributing to higher weed species diversity in no-tillage systems were native to North America (Table 6). As generally predicted (Froud-Williams et al. 1983; Swanton et al. 1993), many of the novel weeds in no tillage were not summer annuals. Only five were strictly summer annuals; the other species were winter annuals, biennials, monocarpic perennials, or perennials. The cessation of fall tillage is predicted to favor winter annuals and the root systems of biennial or perennial weeds such as goat's-beard (Tragopogon dubius L.) or hawkweeds (Hieracium spp.) which are able to persist better without disruption by tillage. Although certain perennial weed species can pose difficulties for management during their first year of growth, perennials in general may be less competitive for the immediately available resources than annuals (Brown and Rice 2000; Dyer and Rice 1997, 1999; Lodge 2000).

Adopting a no-tillage system resulted in increased weed diversity because of the proliferation of novel weeds. These changes in the weed community are unlikely to harm crop yield and weed management, in contrast to fears about adopting alternative management like reduced tillage. Nonetheless, other factors not explored in this study, such as soil properties, regional species distribution, fertilizer use, or other agronomic aspects, could affect weed community dynamics (Andersson and Milberg 1998; Miyazawa et al. 2004). Swanton et al. (1993) outlined a hierarchy of factors that 
TABLE 6. Weed species that contributed to higher weed species diversity in no-tillage systems listed in descending order of abundance.

\begin{tabular}{|c|c|c|c|c|}
\hline Scientific name & Common name & BAYER code & Life history ${ }^{\mathrm{a}}$ & Status ${ }^{\mathrm{b}}$ \\
\hline Conyza canadensis (L.) Cron. & Horseweed & ERICA & $\mathrm{A} / \mathrm{WA} / \mathrm{B}$ & Native \\
\hline Hieracium aurantiacum L. & Orange hawkweed & HIEAU & $\mathrm{P}$ & Introduced \\
\hline Hieracium caespitosum Dumort. & King devil & HIECA & $\mathrm{P}$ & Introduced \\
\hline Hieracium floribundum Wimmer \& Grab. & Yellow devil hawkweed & HIEPO & $\mathrm{P}$ & Introduced \\
\hline Tragopogon dubius Scop. & Western salsify & TRODM & $\mathrm{B} / \mathrm{MP}$ & Introduced \\
\hline Alliaria petiolata (Bieb) Cavara \& Gran & Garlic mustard & ALAPE & $\mathrm{B}$ & Introduced \\
\hline Hesperis matronalis $\mathrm{L}$. & Dame's rocket & HEVMA & $\mathrm{P}$ & Introduced \\
\hline Sisymbrium altissimum $\mathrm{L}$. & Tumble mustard & SSYOF & $\mathrm{A} / \mathrm{WA} / \mathrm{B}$ & Introduced \\
\hline Echinocystis lobata (Michx.) T. \& G. & Wild cucumber & ECNLO & A & Introduced \\
\hline Sicyos angulatus L. & Bur-cucumber & SIYAN & A & \\
\hline Euphorbia cyparissias L. & Cypress spurge & EPHCY & $\mathrm{P}$ & Introduced \\
\hline Veronica officinalis L. & Common speedwell & VEROF & $\mathrm{P}$ & Introduced \\
\hline Viola kitaebeliana Roemer \& Schultes & Field pansy & - & A & Introduced \\
\hline Pilea pumila (L.) Gray & Clearweed & PILPU & A & Native \\
\hline Urtica dioica L. & Stinging nettle & URTDI & $\mathrm{P}$ & Native \\
\hline Galium circaezans Michx. & Wild licorice & - & $\mathrm{P}$ & Native \\
\hline Potentilla argentea $\mathrm{L}$. & Silver cinquefoil & PTLAG & $\mathrm{P}$ & Introduced \\
\hline Geum canadense Jacq. & White avens & - & $\mathrm{P}$ & Native \\
\hline Fumaria officinalis L. & Fumitory & FUMOF & A & Introduced \\
\hline Geranium robertanium L. & Herb-robert & GERRO & W/A & Introduced \\
\hline
\end{tabular}

a Abbreviations: A, annual; WA, winter annual; B, biennial; MP, monocarpic perennial; P, perennial.

b Native to North America, introduced to North America.

may contribute to succession under conservation tillage. Further studies of these factors are needed and weed population dynamics must be monitored and modeled to help predict changes and to develop alternative weed management strategies.

\section{Acknowledgments}

We thank the farmers who participated (anonymously) in the study and allowed us generous access to their crop fields and Dr. Barbara D. Booth for reviewing and editing the manuscript. Funding was provided by the Ontario Ministry of Agriculture and Food (Food Systems 2002), The Tri-Council Program on Agroecosystem Health, The Natural Sciences and Engineering Research Council of Canada, The Canadian Foundation for Innovation, the Ontario Research and Development Challenge Fund.

\section{Literature Cited}

Allmaras, R. R. and R. H. Dowdy. 1985. Conservation tillage systems and their adoption in the United States. Soil Tillage Res. 5:197-222.

Altieri, M. A. 1995. Agroecology: The science of sustainable agriculture. 2nd ed. Boulder, CO: Westview.

Altieri, M. A. and W. H. Whitcomb. 1979. The potential use of weeds in the manipulation of beneficial insects. Hortscience 14:12-18.

Altieri, M. A. and W. H. Whitcomb. 1980. Weed manipulation for insect management in corn. Environ. Manag. 4:483-489.

Andersson, T. N. and P. Milberg. 1998. Weed flora and the relative importance of site, crop, crop rotation, and nitrogen. Weed Sci. 46:3038.

Andow, D. A. 1983. The extent of monoculture and its effects on insect pest populations with particular reference to wheat and cotton. Agric. Ecosyst. Environ. 9:25-35.

Ball, B. C., R. W. Lang, E.A.G. Robertson, and M. F. Franklin. 1994 Crop performance and soil conditions on imperfectly drained loams after 20-25 years of conventional tillage or direct drilling. Soil Tillage Res. 31:97-118.

Ball, D. A. 1992. Weed seedbank response to tillage, herbicides and crop rotation sequence. Weed Sci. 40:654-659.

Ball, D. A. and S. D. Miller. 1993. Cropping history, tillage and herbicide effects on weed flora composition in irrigated corn. Agron. J. 85:817821.
Ball, D. A. and M. A. Shaffer. 1993. Simulating resource competition in multispecies agricultural plant communities. Weed Res. 33:299-310.

Benoit, D. L., C. J. Swanton, K. Chandler, and D. A. Derksen. 1991. Changes in weed populations and seed bank through two cycles of a maize-soyabean rotation in Ontario Canada. Proc. Br. Crop Prot. Conf. - Weeds-1991. 1:403-410.

Bilalis, D., P. Efthimiadia, and N. Sidiras. 2001. Effect of three tillage systems on weed flora in a 3-year rotation with four crops. J. Agron. Crop Sci. 186:135-141.

Blumberg, A. Y. and D. A. Crossley, Jr. 1983. Comparison of soil surface arthropod populations in conventional tillage, no-tillage and old field systems. Agri-Ecosystems 8:247-253.

Brown, C. S. and K. J. Rice. 2000. The mark of Zorro: effects of the exotic annual grass Vulpia myuros on California native perennial grasses. Restor. Ecol. 8:10-17.

Brust, G. E. and G. J. House. 1989. Weed seed destruction by arthropods and rodents in low-input soybean agroecosystems. Am. J. Alt. Agric. 3:19-25.

Buhler, D. D. 1995. Influence of tillage systems on weed population dynamics and management in corn and soybean in the central USA. Crop Sci. 35:1247-1258.

Buhler, D. D., R. G. Hartzler, and F. Forcella. 1997. Implications of weed seedbank dynamics to weed management. Weed Sci. 45:329-336.

Buhler, D. D., D. E. Stoltenberg, R. L. Becker, and J. L. Gunsolus. 1994. Perennial weed populations after 14 years of variable tillage and cropping practices. Weed Sci. 42:205-209.

Cannell, R. Q. and J. D. Hawes. 1994. Trends in tillage practices in relation to sustainable crop production with special reference to temperate climates. Soil Tillage Res. 30:245-282.

Caporali, F. and A. Onnis. 1992. Validity of rotation as an effective agroecological principle for a sustainable agriculture. Agric. Ecosyst. Environ. 41:101-113.

Cardina, J., E. Regnier, and K. Harrison. 1991. Long-term tillage effects on seed banks in three Ohio soils. Weed Sci. 39:186-194.

Cavers, P. B. 1995. Seed banks: memory in soil. Can. J. Soil Sci. 75:1113.

Clay, S. A. and I. Aguilar. 1998. Weed seedbanks and corn growth following continuous corn or alfalfa. Agron. J. 90:813-818.

Clements, D. R., S. F. Weise, and C. J. Swanton. 1994. Integrated weed management and weed species diversity. Phytoprotection 75:1-18.

Clements, D. R., D. Benoit, S. D. Murphy, and C. J. Swanton. 1996. Tillage effects of weed seed return and seedbank composition. Weed Sci. 44:314-322.

Cromar, H. E., S. D. Murphy, and C. J. Swanton. 1999. Influence of tillage 
and crop residue on post-dispersal predation of weed seeds. Weed Sci. 47:184-194.

Dale, M.R.T., A. G. Thomas, E. A. John. 1992. Environmental factors including management practices as correlates of weed community composition in spring seeded crops. Can. J. Bot. 70:1931-1939.

Dekker, J. 1997. Weed diversity and weed management. Weed Sci. 45: $357-363$.

Dekker, J. 1999. Soil weed seed banks and weed management. J. Crop Prod. 2:139-166.

Derksen, D. A. 1991. The influence of agronomic practices on weed communities. Ph.D. thesis, University of Guelph, Guelph, ON. 224 p.

Derksen, D. A. 1996. Weed community ecology: tedious sampling or relevant science? Phytoprotection 77:29-39.

Derksen, D. A., G. P. Lafond, A. G. Thomas, H. A. Loeppky, and C. J. Swanton. 1993. Impact of agronomic practices on weed communities: tillage systems. Weed Sci. 41:409-417.

Derksen, D. A., A. G. Thomas, G. P. Lafond, H. A. Loeppky, and C. J. Swanton. 1994. The influence of agronomic practices on weed communities: fallow within tillage systems. Weed Sci. 42:184-194.

Derksen, D. A., A. G. Thomas, G. P. Lafond, H. A. Loeppky, and C. J. Swanton. 1995. Impact of post-emergence herbicides on weed community diversity within conservation-tillage systems. Weed Res. 35: 311-320.

Dick, W. A. and T. C. Daniel. 1987. Soil chemical and biological properties as affected by conservation tillage: environmental implications. Pages 125-147 in T. J. Logan, J. M. Davidson, J. L. Baker, and M. R. Overcash, eds. Effects of Conservation Tillage on Groundwater Quality. Chelsea, MI: Lewis.

Dorado, J., J. P. Del Monte, and C. López-Fando. 1999. Weed seedbank response to crop rotation and tillage in semiarid agroecosystems. Weed Sci. 47:67-73.

Dyer, A. R. and K. J. Rice. 1997. Intraspecific and diffuse competition: the response of Nassella pulchra in a California grassland. Ecol. Appl. 7:484-492.

Dyer, A. R. and K. J. Rice. 1999. Effects of competition on resource availability and growth in a native bunchgrass in two California grasslands. Ecology 80:2697-2710.

El Titi, A. 1995. Ecological aspects of integrated farming. Pages 243-256 in D. M. Glen, M. P. Greaves and H. M. Anderson, eds. Ecology and Integrated Farming Systems. Chichester, West Sussex, UK: J. Wiley.

Fawcett, R. S., B. R. Christensen, and D. P. Tierney. 1994. The impact of conservation tillage on pesticide runoff into surface water: a review and analysis. J. Soil Water Conserv. 49:126-135.

Forcella, F., K. Eradat-Oskoui, and S. W. Wagner. 1993. Applications of weed seedbank ecology to low-input crop management. Ecol. Appl. 3: 74-83.

Froud-Williams, R. J. 1988. Changes in weed flora with different tillage and agronomic management systems. Pages 213-236 in M. A. Altieri and M. Liebman, eds. Weed Management in Agroecosystems: Ecological Approaches. Boca Raton, FL: CRC Press.

Froud-Williams, R. J., D.S.H. Drennan, and R. J. Chancellor. 1983. Influence of cultivation regime on weed floras of arable cropping systems. J. Appl. Ecol. 20:187-197.

Hendrix, P. E., R. W. Parmelee, D. A. Crossley, Jr., D. C. Coleman, E. P. Odum, and P. M. Groffman. 1986. Detritus food webs in conventional and no-tillage agroecosystems. BioScience 36:374-380.

Hildebrand, P. E., and F. Poey. 1985. On Farm Agronomic Trials in Farming Systems Research and Extension. Boulder, CO: Lynne Riemer Publishers. $162 \mathrm{p}$.

Hinkle, M. K. 1983. Problems with conservation tillage. J. Soil Water Conserv. 38:201-206.

Hoffman, M. L., M.D.K. Owen, and D. D. Buhler. 1998. Effects of crop and weed management on density and vertical distribution of weed seeds in soil. Agron. J. 90:793-799.

House, G. J. and G. E. Brust. 1989. Ecology of low-input, no-tillage agroecosystems. Agric. Ecosyst. Environ. 27:331-345.

House, G. J. and R. W. Parmelee. 1985. Comparison of soil arthropods and earthworms from conventional and no-tillage agroecosystems. Soil Tillage Res. 5:351-360.

House, G. J., B. R. Stinnner, D. A. Crossley, Jr., and E. P. Odum. 1984. Nitrogen cycling in conventional and no-tillage agroecosystems: analysis of pathways and processes. J. Appl. Ecol. 21:991-1012.

Karlen, D. L., N. C. Wollenhaupt, D. C. Erbach, E. C. Berry, J. B. Swan,
N. S. Eash, and J. L. Jordahl. 1994. Crop residue effects on soil quality following 10-years of no-till corn. Soil Tillage Res. 31:149-167.

Kegode, G. O., F. Forcella, and S. Clay. 1999. Influence of crop rotation, tillage, and management inputs on weed seed production. Weed Sci. 47:175-183.

Koskinen, W. C. and C. G. McWhorter. 1986. Weed control in conservation tillage. J. Soil Water Conserv. 38:253-254.

Kremer, R. J. 1993. Management of weed seed banks with microorganisms. Ecol. Appl. 3:42-52.

Légére, A. and N. Samson. 1999. Relative influence of crop rotation, tillage, and weed management on weed associations in spring barley cropping systems. Weed Sci. 47:112-122.

Liebman, M. and E. Dyck. 1993. Crop rotation and intercropping strategies for weed management. Ecol. Appl. 3:92-122.

Lodge, G. M. 2000. Competition among seedlings of perennial grasses, subterranean clover, white clover, and annual ryegrass in replacement series mixtures. Aust. J. Agric. Res. 51:377-383.

Magurran, A. E. 1988. Ecological Diversity and its Measurement. Princeton, NJ: Princeton Univ. Press. 179 p.

Miyazawa, K., H. Tsuji, M. Yamagata, H. Nakano, and T. Nakamoto. 2004. Response of weed flora to combinations of reduced tillage, biocide application and fertilization practices in a 3-year crop rotation. Weed Biol. Manag. 4:24-34.

Ontario Weed Committee. 1996. Guide to Weed Control. Ontario Ministry of Agriculture, Food and Rural Affairs. Publ. 75. 232 p.

Roman, E. S., S. D. Murphy, and C. J. Swanton. 2000. Simulation of Chenopodium album seedling emergence. Weed Sci. 48:217-224.

Schellhorn, N. A. and V. L. Sork. 1997. The impact of weed diversity on insect population dynamics and crop yield in collards, Brassica oleracea (Brassicaceae). Oecologia 111:233-240.

Swanton, C. J. and S. D. Murphy. 1996a. Weed science beyond the weeds: the role of integrated weed management (IWM) in agroecosystem health. Weed Sci. 44:437-445.

Swanton, C. J. and S. D. Murphy. 1996b. Integrated weed management (IWM) promotes increased biodiversity and energy efficiency. Pages 1369-1374. in Proceedings of the Second International Weed Control Congress. Copenhagen, Denmark: International Weed Science Society and European Weed Research Society.

Swanton, C. J. and S. F. Weise. 1991. Integrated weed management: the rationale and approach. Weed Technol. 5:657-663.

Swanton, C. J., D. R. Clements, and D. A. Derksen. 1993. Weed succession under conservation tillage: A hierarchical framework for research and management. Weed Technol. 7:286-297.

Swanton, C. J., A. Shrestha, R. C. Roy, B. R. Ball-Coelho, and S. Z. Knezevic. 1999. Effect of tillage systems, N, and cover crop on the composition of weed flora. Weed Sci. 47:454-461.

Swift, M. J. and A. Anderson. 1993. Biodiversity and ecosystem function in agricultural systems. Pages 15-41 in E. D. Schulze, and H. A. Mooney, eds. Biodiversity and Ecosystem Function. Berlin: SpringerVerlag.

Thomas, A. G. and B. L. Frick. 1993. Influence of tillage systems on weed abundance in southwestern Ontario. Weed Technol. 7:699-705.

Triplett, G. B., Jr. and G. D. Lytle. 1972. Control and ecology of weeds in continuous corn grown without tillage. Weed Sci. 20:453-457.

Weersink, A., M. Walker, C. Swanton, and J. Shaw. 1992a. Economic comparison of alternative tillage systems under risk. Can. J. Agric. Econ. 40:199-217.

Weersink, A., M. Walker, C. Swanton, and J. E. Shaw. 1992b. Costs of conventional and conservation tillage systems. J. Soil Water Conserv. 47:328-334.

Wilson, R. G. 1988. Biology of weed seeds in the soil. Pages 25-39 in M. A. Altieri, and M. Liebman, eds. Weed Management in Agroecosystems: Ecological Approaches. Boca Raton, FL: CRC Press.

Yenish, J. P., J. D. Doll, and D. D. Buhler. 1992. Effects of tillage on vertical distribution and viability of weed seed in soil. Weed Sci. 40: 429-433.

Yiridoe, E. K., T. J. Vyn, A. Weersink, D. C. Hooker, and C. Swanton. 2000. Farm-level profitability analysis of alternative tillage systems on clay soils. Can. J. Plant Sci. 80:65-73.

Yiridoe, E. K., A. Weersink, C. J. Swanton, and R. C. Roy. 1994. Risk efficient choice of bean-winter wheat rotation, cover crop and tillage system on light textured soils. J. Prod. Agric. 7:374-380.

Received June 29, 2004, and approved September 13, 2005. 